\title{
Inhalation of swine dust induces cytokine release in the upper and lower airways
}

\author{
Z. Wang*, K. Larsson*, L. Palmberg*, P. Malmberg*, P. Larsson*, L. Larsson**
}

Inhalation of swine dust induces cytokine release in the upper and lower airways. Z. Wang, K. Larsson, L. Palmberg, P. Malmberg, P. Larsson, L. Larsson. @ERS Journals Ltd 1997.

ABSTRACT: In healthy subjects, acute inhalation of swine dust causes an influx of inflammatory cells into the airways and increased bronchial responsiveness. The exposure may also cause fever and generalized symptoms. It seems likely that proinflammatory cytokines are involved in the response to inhaled swine dust.

Nasal and bronchoalveolar lavage (BAL) were performed before, and 7 and 24 $\mathrm{h}$ after the start of $3 \mathrm{~h}$ exposure to swine dust, during a period of work in a swine confinement building, in 22 healthy subjects. Lavage fluids were analysed with regard to the cellular response and concentrations of interleukin (IL)-1 $\alpha$, IL-1 $\beta$, IL-6 and tumour necrosis factor- $\alpha$ (TNF- $\alpha)$. Each subject carried personal samplers for exposure measurements. Inhalable dust and airborne endotoxin, 3-hydroxylated (2-OH) fatty acid and muramic acid were measured. Bronchial responsiveness to methacholine was investigated 1-2 weeks before and $7 \mathrm{~h}$ after the start of the exposure.

Exposure caused fever $\left(>38^{\circ} \mathrm{C}\right)$ in three subjects, and approximately $25 \%$ of the subjects experienced symptoms. Bronchial responsiveness to methacholine increased by 3.5 (1.6-4.8) doubling doses (median (25th-75th percentile)). Following exposure, granulocytes increased more than $\mathbf{5 0}$ fold in BAL fluid and more than 40 fold in nasal lavage fluid. IL-1 $\alpha$ and IL-1 $\beta$ increased significantly in BAL fluid $(p<0.05)$ and nasal lavage fluid $(p<0.01)$. IL-6 increased 25 fold in BAL and 15 fold in nasal lavage fluid $(\mathbf{p}<0.001)$. TNF- $\alpha$ was below detection limit $\left(0.25 \mathbf{n g}^{\cdot} \mathbf{L}^{-1}\right)$ in most subjects before exposure and increased following exposure to 3.8 (2.4-5.7) and $1.3(0.6-2.3) \mathrm{ng} \cdot \mathrm{L}^{-1}$ in $\mathrm{BAL}$ and nasal lavage fluid, respectively, $(\mathrm{p}<0.001)$. Total inhalable dust was $20.5(14.6-30.0) \mathrm{mg} \cdot \mathrm{m}^{-3}$ and the concentrations of airborne endotoxin, $3-\mathrm{OH}$ fatty acid and muramic acid were $1.2(0.8-1.4), 3.5(2.2-4.5)$ and $0.9(0.3-1.9) \mu \mathrm{g}^{\cdot} \mathrm{m}^{-3}$, respectively. There was a significant correlation between the IL-6 response in BAL fluid and exposure to dust endotoxin activity and 3-OH fatty acids $(p<0.05)$. Otherwise, no significant correlations were found between exposure and the cytokine response.

We conclude that exposure to swine dust causes an intense upper and lower airway inflammation, which involves the proinflammatory cytokines interleukin-1, interleukin-6 and tumour necrosis factor- $\alpha$.

Eur Respir J 1997; 10: 381-387.
*Dept of Occupational Health, National Institute for Working Life, Solna, Sweden. **Dept of Medical Microbiology, University of Lund, Lund, Sweden.

Correspondence: K. Larsson

Dept of Occupational Health

National Institute for Working Life Solna

Sweden

Keywords: Bronchoalveolar lavage endotoxin

interleukin-1

interleukin-6

nasal lavage

tumour necrosis factor- $\alpha$

Received: July 11996

Accepted after revision November 201996

The study was supported by the Swedish Heart Lung Foundation, by grants $90-1608$, 91-0222 and 94-0318 from the Swedish National Work Environmental Fund, by grant 90-6205 from the Swedish Farmers Foundation for Agricultural Research and by grant $94-1383$ from the Swedish Council for Work Life Research.
Swine farmers have increased numbers of inflammatory cells, predominantly neutrophilic granulocytes, in the airways as assessed by bronchoalveolar lavage (BAL) [1]. Exposure to airborne swine dust may cause symptoms, such as headache, fever, fatigue and malaise [2, $3]$, and leads to an intense airway inflammation [3], and increased bronchial responsiveness to methacholine [4], in healthy, previously unexposed subjects. It is not clear which components in the pig house environment are responsible for the airway reaction. Swine dust contains microorganisms, including Gram-positive and Gramnegative bacteria [5]. Lipopolysaccharide (LPS) or endotoxin, is present in the walls of Gram-negative bacteria, and inhalation of LPS causes an intense acute airway inflammation [6]. We have, however, found evidence that endotoxin may not be the sole component in swine dust causing the inflammatory reaction $[7,8]$.
It has previously been demonstrated in healthy subjects, that interleukin-6 (IL-6) and tumour necrosis factor- $\alpha(\mathrm{TNF}-\alpha)$ increase in peripheral blood a few hours after swine dust exposure [9]. IL-6 has systemic effects, and causes fever and induces production of hepatic acute phase proteins [10]. TNF- $\alpha$, acting in close conjunction with interleukin-1 (IL-1), has a variety of effects in the regulation of the local inflammatory response [11]. It is, thus, plausible that these cytokines, which are probably produced and released in the airways following exposure to swine dust, are of importance for the local inflammatory reaction and, to some extent, may explain some of the symptoms following exposure.

The aim of the present study was to evaluate whether or not the proinflammatory cytokines IL-1, IL-6 and TNF- $\alpha$ are produced and released in the upper and lower airways following exposure to airborne swine dust. The 
inflammatory reaction was assessed by BAL and nasal lavage before and after exposure to dust in a swine confinement building. Furthermore, the aim was to evaluate a possible relationship between the airway inflammatory response and exposure to airborne dust. Dust levels of endotoxin were assessed both by a Limulus assay and by analysis of 3-hydroxy (3-OH) fatty acid, whereas levels of peptidoglycan were measured using muramic acid analysis.

\section{Material and methods}

\section{Subjects}

Twenty two (13 males and 9 females) nonsmoking volunteers, 22-50 (median 31) yrs of age, participated in the study. The subjects were previously not, or only occasionally, exposed to farm dust. None of the subjects had a history of allergic or respiratory diseases. None had experienced symptoms from the airways during the last month prior to the investigation. All subjects gave written informed consent, and the study was approved by the local Ethics Committee.

\section{Study design}

Spirometry followed by a bronchial methacholine challenge and BAL were performed on two separate days more than 2 weeks prior to the exposure to swine dust.

On the day of exposure, a nasal lavage was performed in the morning. The subjects were then exposed to swine dust for $3 \mathrm{~h}$ in a swine confinement building containing approximately 700 swine, weighing about 100 $\mathrm{kg}$ each. During these $3 \mathrm{~h}$, the participants assisted the farmer in guiding the pigs through weighing boxes, a procedure that causes considerable aerosolization of settled dust. One or two subjects were exposed on each occasion. Each subject carried a personal dust sampler during the entire exposure period.

Seven hours after the start of exposure, another nasal lavage was performed, followed by spirometry and a bronchial methacholine provocation. Twenty four hours after the start of exposure, a second BAL was performed. Blood samples were drawn before, 5, 7 and $24 \mathrm{~h}$ after the exposure. Oral temperature was measured before, 5 and $7 \mathrm{~h}$ after the start of the exposure. The subjects were also instructed to measure oral temperature if they felt febrile after this time period.

All participants completed a symptom questionnaire, with questions about shivering, headache, weakness, muscle pain and nausea. The symptoms were reported using a five-grade scale (1 - 5), where: 1 denoted no symptom; and 5 indicated very severe symptoms. The subjects were regarded as symptomatic only if they responded with grade 4 or 5 .

\section{Nasal lavage}

The procedure for nasal lavage previously described by BASCOM and PIPKORN $[12,13]$ was used, with minor modifications. During the lavage, the subject was seated with the neck extended to an angle of approximately $45^{\circ}$ and with the soft palate closed. Five millilitres of $0.9 \% \mathrm{NaCl}$ was instilled into each nostril, using a needleless syringe. After $10 \mathrm{~s}$, the subject flexed the neck forward and expelled the liquid into a plastic basin, which was placed on ice during processing.

The volume of the combined lavage portions was measured and centrifuged at $200 \times \mathrm{g}$ for $10 \mathrm{~min}$ at $+4^{\circ} \mathrm{C}$. The supernatant was aliquoted and kept frozen at $-70^{\circ} \mathrm{C}$ until analysis. The pellet was resuspended in $0.9 \% \mathrm{NaCl}$ with $0.1 \%$ human serum albumin (HSA), and the cells were counted in a Bürker chamber and the number of cells $\cdot \mathrm{mL}^{-1}$ of recovered fluid calculated. Cytocentrifugeprepared slides were stained with May-Grünwald Giemsa stain and 300 cells were counted for cell differentials.

\section{Bronchoalveolar lavage (BAL)}

Bronchoscopy was performed through the mouth with a flexible fibreoptic bronchoscope (Type 4B2; Olympus Optical Co. Ltd, Japan) under local anaesthesia with 2\% lidocaine (xylocaine ${ }^{\circledR}$; Astra, Södertälje, Sweden) after premedication with benzodiazepine and atropine. The bronchoscope was wedged in a middle lobe bronchus, and sterile saline solution at $37^{\circ} \mathrm{C}$ was instilled in five aliquots of $50 \mathrm{~mL}$. After each instillation, the fluid was gently aspirated and collected in a siliconized plastic bottle kept on ice. The cellular component was immediately centrifuged at $400 \times \mathrm{g}$ for $5 \mathrm{~min}$ at $4{ }^{\circ} \mathrm{C}$, and the supernatant was frozen in aliquots at $-70^{\circ} \mathrm{C}$ for subsequent analysis. The BAL technique has been described in detail previously [14].

The pellet was resuspended in Hank-Tris solution (Hank's solution Tris buffer $0.17 \mathrm{~mol} \cdot \mathrm{L}^{-1}, \mathrm{pH} 7.4, \mathrm{SBL}$ No. 56122; Stockholm, Sweden) and the cells were counted in a Bürker chamber. Smears for differential counts were prepared by cytocentrifugation after staining with May-Grünwald Giemsa. Four hundred cells were counted. The viability of the cells was measured by trypan blue exclusion.

\section{Analyses in BAL and nasal lavage fluid}

The concentrations of interleukin- $1 \alpha$ and $-1 \beta$ (IL- $1 \alpha$ and IL-1 $\beta$ ) interleukin-6 (IL-6) and tumour necrosis factor- $\alpha$ (TNF- $\alpha)$ in lavage fluids were measured in duplicate by enzyme-linked immunosorbent assay (ELISA). For IL-1 $\beta$, IL-6 and TNF- $\alpha$, a Quantikine ${ }^{\mathrm{TM}}$ high sensitivity (HS), two-site (sandwich) ELISA kit (R\&D Systems Europe, Abingdon, UK) was used. The Quantikine ${ }^{\mathrm{TM}}$ HS immunoassay uses an enzyme amplification system with alkaline phosphatase as described previously [15]. The lower detection limit of the assay for IL-1 $\beta$, IL-6 and TNF- $\alpha$ was $0.125,0.156$ and $0.25 \mathrm{ng} \cdot \mathrm{L}^{-1}$, respectively. If the concentration detected was above the standard curve the assay was repeated using a diluted sample and (normal sensitivity) Quantikine ${ }^{\mathrm{TM}}$ kits (R\&D Systems Europe, Abingdon, UK).

As a control experiment, BAL fluid from seven subjects, obtained before and after exposure, was concentrated 14 fold by lyophilization and was subsequently analysed using Quantikine ${ }^{\mathrm{TM}}$ IL-6 and TNF- $\alpha$ kits (R\&D Systems Europe, Abingdon, UK). The results were compared with those obtained by using the Quantikine ${ }^{\mathrm{TM}}$ high sensitivity kit in nonconcentrated BAL fluid obtained from the same subjects in the same experiment.

IL- $1 \alpha$ was analysed using a commercially available kit (R\&D Systems Europe, Abingdon, UK) with ELAST ${ }^{\circledR}$ amplification system (DuPont, Nen ${ }^{\circledR}$, Boston, MA, USA). 
After conjugation with the second antibody, biotinyltyramide solution (1\%) was added to each well of the microplate and the incubation lasted for $15 \mathrm{~min}$ at room temperature. The samples were then incubated with 1:500 streptavidin-horseradish peroxidase (HRP) for $30 \mathrm{~min}$ and the ELISA substrate was added. The standard curve for IL- $1 \alpha$ included measurements between 0.49 and 31.3 $\mathrm{ng} \cdot \mathrm{L}^{-1}$. Due to lack of lavage fluids, IL- $1 \beta$ was analysed in nasal lavage fluid from 19 subjects and in BAL fluid from 10 subjects, and IL- $1 \alpha$ was analysed in lavage fluids from 10 subjects.

HSA was measured using inhibition ELISA. HSA (Sigma, St Louis, MO, USA) in phosphate-buffered saline (PBS) $/ 0.15 \%$ Kathon ${ }^{\mathrm{TM}} \mathrm{CG}$ at $10 \mu \mathrm{g} \cdot \mathrm{mL}^{-1}$ was bound to 96-well microtitre plates (Maxisorp, Nunc, Denmark) overnight at room temperature. After washing, standard dilutions $\left(0.11-9 \mu \mathrm{g} \cdot \mathrm{mL}^{-1}\right)$ of HSA, a human serum protein calibrator (Dakopatts, Copenhagen, Denmark), nasal lavage or BAL fluid were added to the wells in duplicate. The nasal lavage and BAL fluid were diluted 50 and 100 times, respectively, in PBS/0.1\% Tween 20/0.15\% Kathon/1 mM ethylenediamine tetra-acetic acid (EDTA)/1 M NaCl (dilution buffer). Peroxidaseconjugated rabbit anti-human albumin (Dakopatts, Copenhagen, Denmark) was added and incubated for $1 \mathrm{~h}$ at room temperature after mixing the plate. After washing, the substrate TM Blue (soluble form, TSI-CDP, Milford, MA, USA) was added, and the reaction terminated after 15 min with $1 \mathrm{M} \mathrm{H}_{2} \mathrm{SO}_{4}$. Absorbance was read at 450- $650 \mathrm{~nm}$ using a Thermomax 250 reader (Molecular Devices, Sunnyvale, CA, USA), and the results were analysed with Softmax ${ }^{\circledR}$ software (Molecular Devices, Sunnyvale, CA, USA). For duplicate intra-assay and interassay samples coefficients of variation (CVs) of $<10$ and $20 \%$, respectively, were accepted. The CVs of the intra-assay and interassay variation were 4.3 and $7.4 \%$, respectively.

\section{Analyses in blood}

IL-6 in serum was analysed with Quantikine ${ }^{\text {TM }}$ IL-6 kits (R\&D Systems Europe, Abingdon, UK).

\section{Lung function and bronchial responsiveness}

Forced expiratory volume in one second (FEV1) and vital capacity (VC) were measured according to the American Thoracic Society (ATS) criteria [16] with a low resistance rolling-seal spirometer (OHIO model 840; Airco, Madison, WI, USA). Local reference values were used $[17,18]$.

Bronchial responsiveness was assessed by a methacholine provocation test. Inhalation of diluent was followed by inhalation of doubling concentrations of methacholine starting at $0.5 \mathrm{mg} \cdot \mathrm{mL}^{-1}$. The challenge was stopped either when FEV1 had decreased by $20 \%$ compared to the value obtained after inhalation of diluent, or after inhalation of the highest methacholine concentration $\left(32 \mathrm{mg} \cdot \mathrm{mL}^{-1}\right)$. The cumulative dose causing a $20 \%$ decrease in FEV1 (PD20) was calculated. The method is standardized with regard to inhalation flow $\left(0.4 \mathrm{~L} \cdot \mathrm{s}^{-1}\right)$ and volume $\left(0.8 \mathrm{~L} \cdot\right.$ breath $^{-1}, 15$ breaths during $60 \mathrm{~s}$ ). The details of the procedure have been described previously [19].

\section{Exposure measurements}

Dust was sampled at an airflow of $2.0 \mathrm{~L} \cdot \mathrm{min}^{-1}$ with personal samplers using $25 \mathrm{~mm}$ head open-phase filter cassettes (IOM) and air suction pumps (SKC Ltd, Dorset, UK). The cassettes were carried in the breathing zone and were equipped with $0.4 \mathrm{~mm}$ polycarbonate filters (Nuclepore ${ }^{\circledR}$, Costar Corp. Headq., Cambridge, MA, USA). Total dust was measured by weighing (Mettler ${ }^{\circledR}$ ME 22 balance; Mettler, Greisensee, Switzerland) after $24 \mathrm{~h}$ of conditioning and compared with reference filters.

Endotoxin was extracted from filters by shaking in $10 \mathrm{~mL}$ of pyrogen-free water for $60 \mathrm{~min}$. The extracts were centrifuged for $10 \mathrm{~min}$ at $1,000 \times \mathrm{g}$ and the supernatants were frozen at $-70^{\circ} \mathrm{C}$ until analysis. Endotoxin was measured after dilution with a chromogen version of Limulus amebocyte lysate assay (QCL-1000; Endotoxin, BioWhittaker, Walkersville, USA, with Escherichia coli 0111:B4 as standard).

Aliquots of the filter extracts were transferred to test tubes equipped with Teflon-lined screw caps, dried, and heated over night at $100^{\circ} \mathrm{C}$ in $4 \mathrm{M}$ hydrochloric acid. One millilitre of hexane was then added to each tube and the hexane phase was transferred to a separate tube after shaking. After evaporation of the hexane phase to dryness, the sample was heated overnight in $4 \mathrm{M}$ methanolic hydrochloric acid at $100^{\circ} \mathrm{C}$, extracted, purified by using a disposable silica gel column and subjected to trimethylsilyl (TMS) derivatization. The molecular weight of environmental LPS is approximately 8,000 and contains four hydroxylated fatty acids. The number of 3-OH fatty acid moles was, therefore, divided by 4 and multiplied by 8,000 to give an estimate of the LPS weight. Analysis of 3-OH fatty acid was then performed as described previously [20]. The aqueous (acidic) phase was evaporated, subjected to TMS derivatization, and analysed for muramic acid [21]. Muramic acid forms $10-20 \%$ of the total peptidoglycan mass. The peptidoglycan content was, thus, estimated by multiplication of the muramic acid concentration by 100/15.

\section{Statistics}

Results are presented as medians (25th-75th percentiles) with the exception of lung function parameters, which are presented as mean values (SEM). For comparisons, Wilcoxon signed rank tests were used. Differences were considered significant when the p-value was less than 0.05. Correlations were calculated with Spearmans rank correlation. For comparisons between cytokine measurements with different kits, Pearson's coefficient of correlation was used.

\section{Results}

The oral temperature was $36.2^{\circ} \mathrm{C}$ (range $36.1-36.4^{\circ} \mathrm{C}$ ) prior to exposure and increased to $37.0^{\circ} \mathrm{C}$ (range $36.7-37.4^{\circ} \mathrm{C}$ ) following exposure. Three subjects had oral temperature $>38^{\circ} \mathrm{C}$. Twenty one of the 22 subjects responded to the questionnaire (table 1). Two experienced shivering, two headache, three malaise and one muscle pain, according to our estimation of significant symptoms. No symptoms were recorded prior to exposure. 
Table 1. - Symptoms in 21 subjects following exposure to swine dust

\begin{tabular}{cccccc}
\hline $\begin{array}{c}\text { Symptom } \\
\text { score }\end{array}$ & $\begin{array}{c}\text { Shivering } \\
\mathrm{n}\end{array}$ & $\begin{array}{c}\text { Headache } \\
\mathrm{n}\end{array}$ & $\begin{array}{c}\text { Malaise } \\
\mathrm{n}\end{array}$ & $\begin{array}{c}\text { Muscle pain } \\
\mathrm{n}\end{array}$ & $\begin{array}{c}\text { Nausea } \\
\mathrm{n}\end{array}$ \\
\hline 1 & 10 & 13 & 6 & 18 & 17 \\
2 & 7 & 2 & 5 & 0 & 1 \\
3 & 2 & 4 & 7 & 2 & 3 \\
4 & 2 & 2 & 3 & 1 & 0 \\
5 & 0 & 0 & 0 & 0 & 0 \\
\hline
\end{tabular}

Symptom score 4 and 5 are considered to be significant.

\section{$B A L$ and nasal lavage fluid analyses}

The granulocyte concentration in BAL fluid increased more than 50 fold (from $1.9(1.0-2.4)$ to 107 (53-199) $\times 10^{6}$ cells $\left.\cdot \mathrm{L}^{-1} ; \mathrm{p}<0.001\right)$. The number of lymphocytes and monocytes was more than doubled following exposure (from $4.9(3.1-8.7)$ to $10.0(6.3-19.9) \times 10^{6}$ cells $\cdot \mathrm{L}^{-1}$ and from $85(68-99)$ to $188(133-275) \times 10^{6}$ cells $\cdot \mathrm{L}^{-1}$, respectively; $\mathrm{p}<0.01$ and $\mathrm{p}<0.001)$.

The total cells in nasal lavage fluid increased from 3.6 $(1.8-7.4) \times 10^{6}$ cells $\cdot \mathrm{L}^{-1}$ before exposure to $79(35-185)$ $\times 10^{6}$ cells $\cdot \mathrm{L}^{-1}$ after exposure. Prior to exposure, differential count was possible in nasal lavage fluid in only 13 subjects. In these subjects there was an increase in neutrophils from $2.7(0.3-13.1)$ to $121(45-229) \times 10^{6}$ cells $\cdot \mathrm{L}^{-1}$.

The results of the cytokine analyses are presented in figures 1 and 2. Following exposure, TNF- $\alpha$ and IL-6 increased in BAL fluid in all subjects and the levels of IL- $1 \alpha$ and IL- $1 \beta$ were unchanged (below detection limit) in four and two subjects, respectively, but increased in all other subjects. In nasal lavage fluid, TNF- $\alpha$ and IL-6
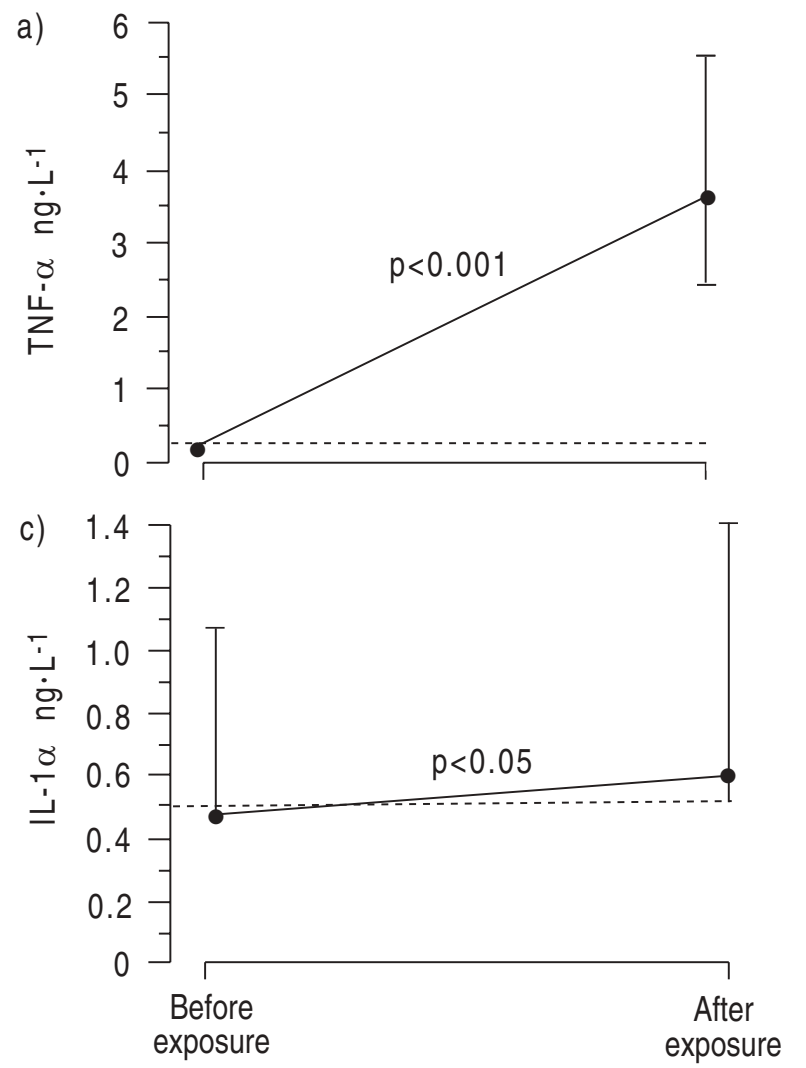
$3.8(2.4-5.7)$ and $1.3(0.6-2.3) \mathrm{ng} \cdot \mathrm{L}^{-1}$, respectively, after exposure $(\mathrm{p}<0.001)$. IL-6 concentration increased more than 25 fold (from $0.43(0.21-0.78)$ to $11.6(8.1-21.0)$ $\left.\mathrm{ng} \cdot \mathrm{L}^{-1} ; \mathrm{p}<0.001\right)$ in BAL fluid and 15 fold in nasal lavage fluid (from $1.4(0.6-2.6)$ to $21(14-40) \mathrm{ng} \cdot \mathrm{L}^{-1} ; \mathrm{p}<0.001$ ). In BAL fluid, there was a slight but significant increase in IL- $1 \alpha$ and IL-1 $\beta(p<0.05)$, while the increases in nasal lavage fluid were more pronounced: $3.2(2.2-5.8)$ to 6.0 (5.6-9.3) ng $\cdot \mathrm{L}^{-1}(\mathrm{p}<0.01)$ and $2.6(0.8-3.9)$ to $8.5(6.2-19.8)$ $\mathrm{ng} \cdot \mathrm{L}^{-1}(\mathrm{p}<0.001)$, respectively.

There was a good correlation between measurements using the high sensitivity kit and normal kits on concentrated samples (Pearson's $\mathrm{r}^{2}=0.96$ for IL-6, and 0.62 for $\mathrm{TNF}-\alpha ; \mathrm{p}<0.001)$.

The albumin concentration in BAL and nasal lavage fluid approximately doubled from 19 (14-25) to 40 $(25-47) \mathrm{mg} \cdot \mathrm{L}^{-1}(\mathrm{p}<0.001)$ and from $12(10-20)$ to 33 $(23-66) \mathrm{mg} \cdot \mathrm{L}^{-1}(\mathrm{p}<0.001)$, respectively.

IL-6 concentration in venous blood increased from $0.6(0.3-0.9)$ to $19.2(5.8-32.9) \mathrm{ng} \cdot \mathrm{L}^{-1} 5 \mathrm{~h}$ after exposure, and decreased to $9.9(4.8-25.9)$ and $1.4(1.1-2.0)$
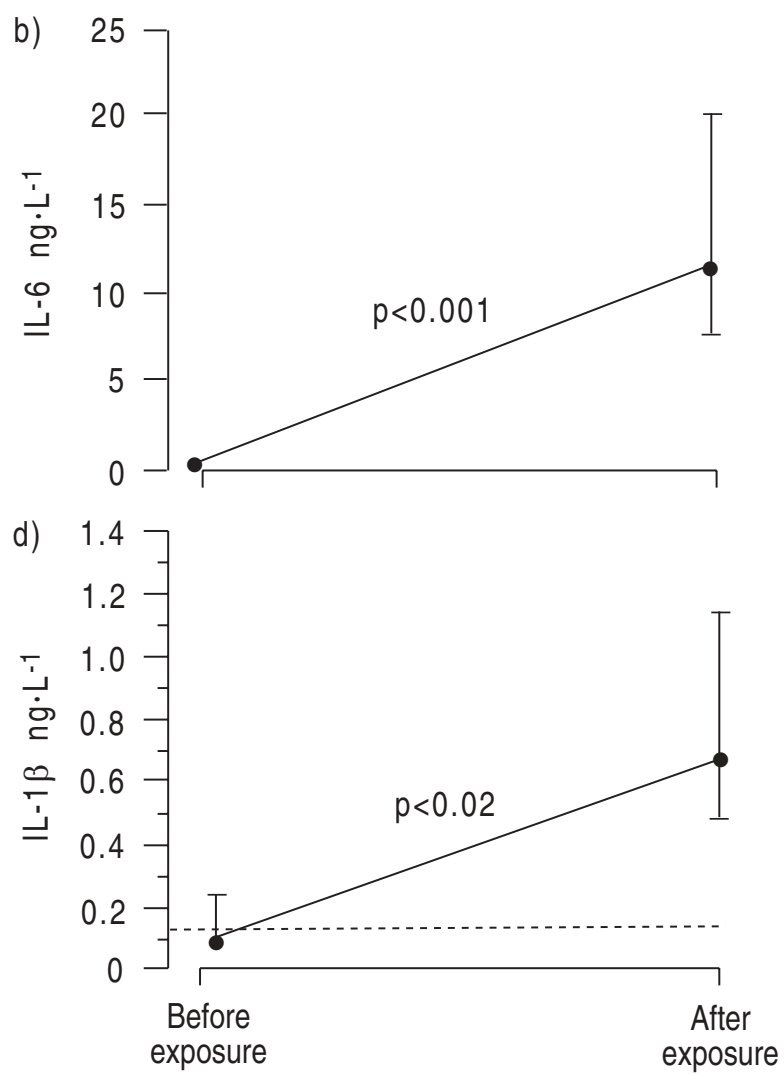

Fig. 1. - Cytokine concentration in bronchoalveolar lavage fluid before and $24 \mathrm{~h}$ after the start of exposure to swine dust. Median and 25 th-75th percentiles are presented. a) Tumour necrosis factor- $\alpha$ (TNF- $\alpha$ ); b) interleukin-6 (IL-6); c) interleukin-1 $\alpha$ (IL-1 $\alpha$ ); d) interleukin-1 $\beta$ (IL-1 $\beta$ ). -----: detection limit. 

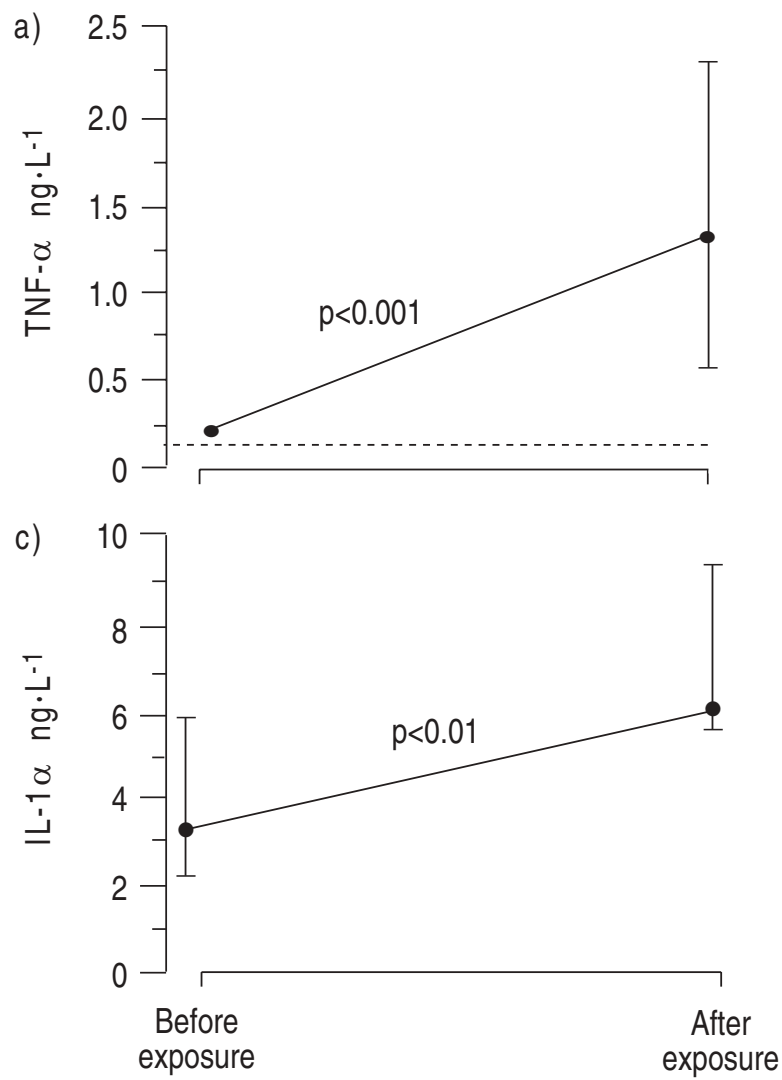
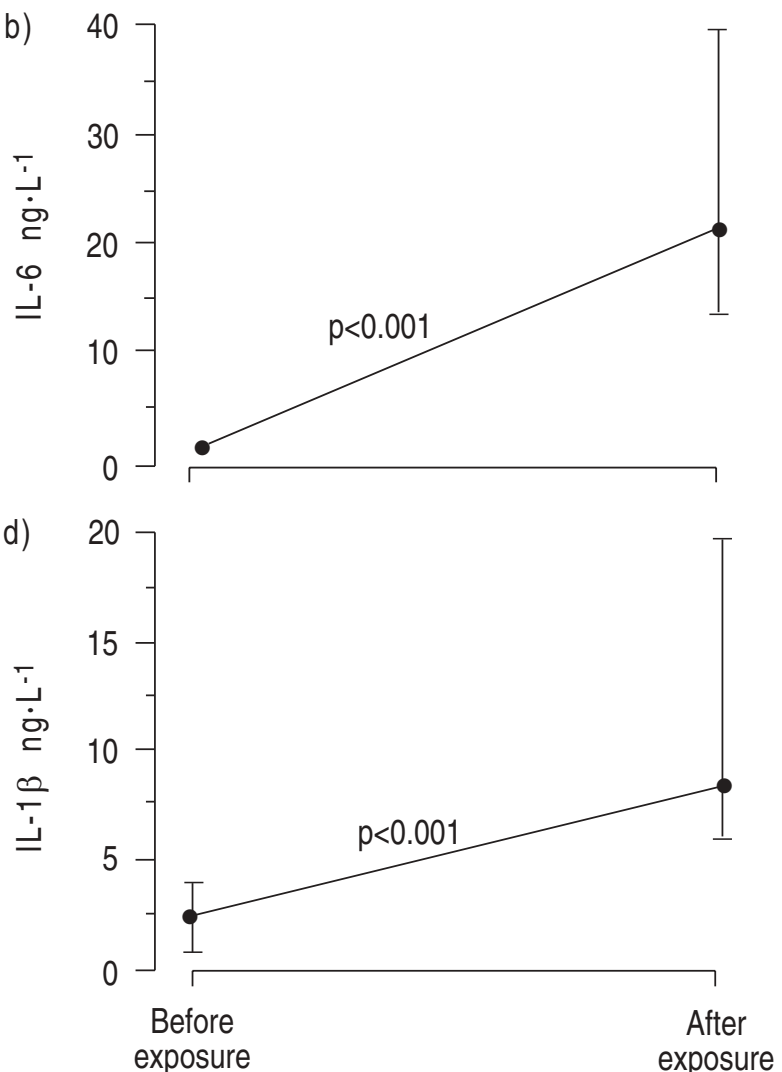

Fig. 2. - Cytokine concentration in nasal lavage fluid before and $7 \mathrm{~h}$ after the start of exposure to swine dust. Median and 25 th-75th percentiles are presented. a) Tumour necrosis factor- $\alpha$ (TNF- $\alpha$ ); b) interleukin-6 (IL-6); c) interleukin-1 $\alpha$ (IL-1 $\alpha$ ); d) interleukin-1 $\beta$ (IL-1 $\beta$ ). -----: detection limit.

$\mathrm{ng} \cdot \mathrm{L}^{-1} 7$ and $24 \mathrm{~h}$ after exposure, respectively. All postexposure values were significantly higher than the preexposure values $(\mathrm{p}<0.001)$.

\section{Lung function and bronchial responsiveness}

Pre-exposure FEV1 and VC were 101 (1) and 104 (2) $\%$ of predicted value. FEV1 fell by $5 \%$ (4.4 (0.2) to 4.2 $(0.2) \mathrm{L} ; \mathrm{p}<0.001)$ and $\mathrm{VC}$ by $2 \%(5.4(0.2)$ to $5.3(0.2)$ $\mathrm{L} ; \mathrm{p}<0.01) 7 \mathrm{~h}$ after the start of exposure.

PD20 for methacholine fell from $5.2(1.3-24.4) \mathrm{mg}$ before exposure to $0.7(0.2-1.2) \mathrm{mg}$ after exposure $(\mathrm{p}<$ 0.001 , which corresponds to a decrease by 3.5 (1.64.8) doubling doses of methacholine. PD20 following exposure was decreased in all subjects and was less than half the value before exposure in 20 out of the 22 participants.

\section{Exposure}

Total airborne inhalable dust concentration was 20.5 $(14.6-30.0) \mathrm{mg} \cdot \mathrm{m}^{-3}$. The endotoxin concentration was $1.2(0.8-1.4) \mu \mathrm{g} \cdot \mathrm{m}^{-3}$ according to the Limulus analysis, and $3.5(2.2-4.5) \mu \mathrm{g} \cdot \mathrm{m}^{-3}$ according to $3-\mathrm{OH}$ fatty acid analyses. The concentration of muramic acid $0.9(0.3-$ 1.9) $\mu \mathrm{g} \cdot \mathrm{m}^{-3}$ corresponded to a peptidoglycan concentration of $6.0(2.0-12.7) \mu \mathrm{g} \cdot \mathrm{m}^{-3}$.

\section{Correlations}

There was a significant correlation between postexposure IL-6 levels in BAL fluid and the inhaled dust endotoxin activity $(\mathrm{Rho}=0.49 ; \mathrm{p}<0.05)$ and $3-\mathrm{OH}$ fatty acid content $(\mathrm{Rho}=0.47 ; \mathrm{p}<0.05)$. No other significant correlations were found between exposure and the cytokine response in lower or upper airways. A weak but significant correlation was found between the increase in albumin in BAL fluid and the endotoxin activity in inhaled dust $($ Rho $=0.48 ; \mathrm{p}<0.05)$.

Postexposure levels of IL- 6 and TNF- $\alpha$ in BAL were significantly correlated with the increase in granulocytes (Rho $=0.55 ; \mathrm{p}<0.02$ for both). Otherwise, no significant correlation was found between the cellular reaction and the cytokine response.

The increase in bronchial responsiveness (PD20 doubling doses) did not correlate significantly with the cellular or cytokine response.

\section{Discussion}

In the present study, it has been confirmed that exposure to swine dust causes symptoms, such as fever, headache and malaise, intense airway inflammation, with a dramatic influx of inflammatory cells into the upper and lower airways, and increased bronchial responsiveness $[3,4,22]$. In addition, we have shown that inhaled swine dust causes a release of the proinflammatory cytokines, TNF- $\alpha$, IL-6, IL- $1 \alpha$ and IL-1 $\beta$, in the upper and lower airways. There are many cell types, such as monocytes, macrophages, lymphocytes, fibroblasts, neutrophils, epithelial and endothelial cells, in the airways, which are capable of IL-1 production [23]. Both IL-1 $\alpha$ and IL- $1 \beta$ could be produced by one cell type but there 
are also cells which are specialized to produce IL-1 of one or the other type. Thus, monocytes/macrophages are the major source of IL-1 $\beta$ [24], whilst T-cells are predominantly IL- $1 \alpha$ producers [25]. IL-6 is produced by epithelial and endothelial cells, monocytes/macrophages and lymphocytes [26], and alveolar macrophages are the major source of TNF- $\alpha$ in the lower airways [11]. We have previously demonstrated that swine dust induces secretion of IL-6 (but not IL- 1 and TNF- $\alpha$ ) from a bronchial epithelial cell line [27], and IL-6, IL-1 $\beta$ and TNF$\alpha$ from alveolar macrophages in vitro [28]. It thus seems probable that an important source of the cytokines found in BAL fluid in the present study are epithelial cells and alveolar macrophages.

It is not clear which cells are responsible for the cytokine production in the nose. Nasal epithelial cells may be one of the major sources for IL-1 and TNF- $\alpha$ [29]. In the present study, we could not demonstrate an increase in cells other than neutrophils in nasal lavage fluid following exposure. However, macrophages, dendritic cells and lymphocytes are known to be increased in the nasal mucosa in rhinitis [30], and may also have been of importance as sources of cytokines in the present study.

The exposure took place whilst weighing pigs. This procedure results in a high degree of agitation and aerosolization of settled dust and the exposure to airborne dust is very high. We found a concentration of airborne dust which was about twice as high as that found in pig houses during regular working shifts [5]. It is not clear which are the components in swine dust that are responsible for the inflammatory reaction. Air sampled from pig confinement buildings contains grain dust, ammonia, fungi and bacteria, mostly Gram-positive but also Gram-negative [5]. LPS from endotoxin in Gram-negative bacteria is a potent stimulus for cytokine production in alveolar macrophages, and inhalation of endotoxin induces airway inflammation with a cellular reaction dominated by neutrophils [6]. Although endotoxin could be responsible for the airway reaction, there are findings indicating that other components are probably of importance. Studies in our laboratory have shown that swine dust is more potent than LPS in stimulating the release of IL-6 and IL-8 from epithelial cells [7], whilst LPS seems to be a more potent stimulus than swine dust inducing production of those cytokines in alveolar macrophages (unpublished observation).

TNF- $\alpha$ and IL- 1 influence cell migration during inflammatory reactions. These cytokines act synergistically on the stimulation of polymorphonuclear neutrophilic granulocyte migration [31], and stimulate vascular endothelial cells to promote transendothelial passage of neutrophils, albumin, and fluid in vitro and in animal experiments [3234]. TNF- $\alpha$, IL-1 and LPS induce the expression of the adhesion molecules intercellular adhesion molecule-1 (ICAM-1), vascular cell adhesion molecule-1 (VCAM1) and E-selectin on endothelial cells, promoting adhesion to granulocytes, monocytes and lymphocytes [3538]. The production of TNF- $\alpha$ and IL-1 in the upper and lower airways could, thus, contribute to the influx of inflammatory cells following exposure. There are results from animal experiments supporting such an assumption [39]. It is, however, plausible that other mechanisms are also of importance. We have shown that interleukin-8 (IL-8) [21] and leukotriene $\mathrm{B}_{4}\left(\mathrm{LTB}_{4}\right)$ increase in lavage fluid following exposure to swine dust (unpublished observations). Both these mediators are potent chemotactic factors for inflammatory cells and probably contributed to the chemoattraction of granulocytes and lymphocytes in the present setting.

Data from animal experiments suggest that the cytokine production commences less than $1 \mathrm{~h}$ following exposure to endotoxin [40]. We have previously shown that TNF- $\alpha$ and IL-6 reach maximal levels in peripheral blood 2-5 $\mathrm{h}$ and $4-11 \mathrm{~h}$ after exposure, respectively [9]. Although the blood concentrations were not followed in detail in the present study, the data support our previous findings. In the present study, there were still high cytokine concentrations in the lavage fluid although BAL was performed $24 \mathrm{~h}$ after exposure. We do not know the time course for the airway reaction and the BAL fluid is obtained at a time-point when it is not clear whether the inflammatory reaction is increasing or declining. The exposure may induce an acute inflammatory reaction, which continuously decreases after exposure although it is still detectable $24 \mathrm{~h}$ after exposure. There is also a possibility that the inhalation of dust leads to airway deposition and that deposited material acts as a continuous stimulus for the inflammatory response.

We did not find a correlation between the inflammatory response and the increase in bronchial responsiveness on an individual basis. For two reasons, such a relationship should not necessarily be anticipated. Firstly, the BAL does not primarily reflect the reaction in the airways, but rather in more peripheral airways, predominantly the alveolar space. Secondly, the bronchial methacholine challenge was performed $7 \mathrm{~h}$ after exposure, i.e. at a time-point when the cellular and cytokine responses in the lower airways were not studied. The present study was not designed to give information about the relationship between airways inflammation and the increase in bronchial responsiveness.

In conclusion, we have demonstrated that three hours exposure to dust in a pig house leads to an intense inflammation in upper and lower airways and that this reaction involves cytokines, such as interleukin-1 and 6 and tumour necrosis factor- $\alpha$.

Acknowledgements: The authors thank C. Müller-Suur, A. Saraf, B-M. Larsson and S. Siljerud for technical assistance.

\section{References}

1. Larsson K, Eklund A, Malmberg P, Belin L. Alterations in bronchoalveolar lavage fluid but not in lung function and bronchial responsiveness in swine confinement workers. Chest 1992; 101: 767-774.

2. Wilhelmsson J, Bryngelsson I-L, Ohlsson C-G. Respiratory symptoms among Swedish swine producers. Am J Ind Med 1989; 15: 311-318.

3. Larsson K, Eklund A, Hansson L-O, Isaksson B-M, Malmberg P. Swine dust cause intense airways inflammation in healthy subjects. Am J Respir Crit Care Med 1994; 150: 973-977.

4. Malmberg P, Larsson K. Acute exposure to swine dust causes bronchial hyperresponsiveness in healthy subjects. Eur Respir J 1993; 6: 400-404.

5. Crock B, Robertson JF, Travers Glass SA, Botheroyd EM, Lacey J, Topping MD. Airborne dust, ammonia, microorganism, and antigens in pig confinement houses 
and the respiratory health of exposed farm workers. $A m$ Ind Hyg Assoc J 1991; 52: 271-279.

6. Sandström T, Bjermer L, Rylander R. Lipopolysaccharide (LPS) inhalation in healthy subjects increases neutrophils, lymphocytes and fibronectin levels in bronchoalveolar lavage fluid. Eur Respir J 1992; 5: 992-996.

7. Palmberg L, Isaksson B-M, Larsson K, Malmberg P. Swine dust is more potent than LPS to induce interleukin-8 production in a pulmonary epithelial cell line. Eur Respir J 1994; 7: 73s.

8. Larsson B-M, Palmberg L, Larsson K, Malmberg P. Gram-positive bacteria induce IL-8 production in epithelial cell line A549. Eur Respir J 1995; 8: 225s.

9. Wang Z, Malmberg P, Larsson P, Larsson B-M, Larsson $\mathrm{K}$. Time course of interleukin-6 and TNF-alpha increase in serum following inhalation of swine dust. Am J Respir Crit Care Med 1996; 153: 147-152.

10. Zitnik RJ, Elias JA. Interleukin-6 and the lung. In: Kelley J, ed. Cytokines of the Lung. New York, Marcel Dekker Inc., 1993; pp. 229-280.

11. Ulich TR. Tumor necrosis factor. In: Kelley J, ed. Cytokines of the Lung. New York, Marcel Dekker, 1993; pp. 307-332.

12. Pipkorn U, Karlsson G, Enerbäck L. A brush method to harvest cells from the nasal mucosa for microscopic and biochemical analysis. J Immunol Methods 1988; 112: 37-42.

13. Bascom R, Pipkorn U, Lichtenstein LM, Naclerio RM. The influx of inflammatory cells into nasal washings during the late response to antigen challenge. Am Rev Respir Dis 1988; 138: 406-412.

14. Eklund A, Blaschke E. Relationship between changed alveolar-capillary permeability and angiotensin-converting enzyme activity in serum in sarcoidosis. Thorax 1986; 41: 629-634.

15. Self SE. Enzyme amplification: a general method applied to provide an immunoassisted assay for placental alkaline phophatase. J Immunol Methods 1985; 76: 389-393.

16. American Thoracic Society (ATS). American Thoracic Society: standardization of spirometry. Am Rev Respir Dis 1987; 136: 1258-1298.

17. Hedenström H, Malmberg P, Fridriksson H. Reference values for lung function tests in men: regression equations with smoking variables. Uppsala J Med Sci 1986; 91: 299-310.

18. Hedenstrom H, Malmberg P, Agarwal K. Reference values for lung function tests in females: regression equations with smoking variables. Clin Respir Physiol 1985; 21: 551-557.

19. Malmberg P, Larsson K, Thunberg S. Increased lung deposition and biological effect of methacholine by use of a drying device for bronchial provocation tests. Eur Respir J 1991; 4: 890-898.

20. Mielniczuk Z, Mielniczuk E, Larsson L. Gas chromatography-mass spectrometry methods for analysis of 2and 3-hydroxylated fatty acid: application for endotoxin measurement. J Microbiol Methods 1993; 17: 91-102.

21. Elmroth I, Fox A, Larsson L. Determination of bacterial muramic acid by gas chromatography-mass spectrometry with negative-ion detection. J Chromatogr 1993; 628: 93-102.

22. Isaksson B-M, Palmberg L, Malmberg P. Increased IL8 levels in nasal lavage after inhalation of swine dust. Eur Respir J 1994; 7 (Suppl. 18): 314s.

23. Aksamit TR, Hunninghake GW. Interleukin-1. In: J. Kelley, ed. Cytokines of the Lung. New York, Marcel Dekker, 1993; pp. 185-228.
24. March CJ, Mosley B, Larsen A, et al. Cloning, sequence, and expression of two distinct human interleukin- 1 complementary DNAs. Nature 1985; 315: 641-647.

25. Acres RB, Larsen A, Conlon PJ. IL-1 expression in a clone of human T-cells. J Immunol 1987; 138: 2132-2136.

26. Ray A, Tatter SB, Santhanam U, Helfgott DC, May LT, Sehgal PB. Regulation of expression of interelukin-6: molecular and clinical studies. Ann NY Acad Sci 1989; 557: 353-362.

27. Ek A, Larsson B-M, Palmberg L, Larsson K. Glucocorticoids inhibit the release of cytokines from epithelial cells. Eur Respir J 1996; 9 (Suppl. 23): 126s.

28. Wang Z, Malmberg P, Larsson K, Palmberg L. Cytokine production by epithelial cells and macrophages following exposure to swine dust and LPS. Am J Respir Crit Care Med 1996; 153: A614.

29. Davies RJ, Devalia JL. Epithelial cell dysfunction in rhinitis. In: Busse WW, Holgate ST, eds. Asthma and Rhinitis. Boston, Blackwell Scientific Publications, 1995; pp. $612-624$.

30. Okuda M. Migrating cells in the epithelium of allergic nasal mucosa. Rhinology 1988; 26 (Suppl. 1): 136.

31. Wankowicz, Z, Megyeri P, Issekutz A. Synergy between TNF and IL-1 in the induction of polymorphonuclear leukocyte migration during inflammation. J Leukocyte Biol 1988; 43: 349-356.

32. Stephens KE, Ishizaka A, Larrick JW, Raffin TA. Tumor necrosis factor causes increased pulmonary permeability and edema: comparison to septic acute lung injury. Am Rev Respir Dis 1988; 137: 1364-1370.

33. Moser R, Schleiffenbaum B, Groscurth P, Fehr J. Interleukin-1 and tumor necrosis factor stimulate human vascular endothelial cells to promote transendothelial neutrophil passage. J Clin Invest 1989; 83: 444-455.

34. Goldblum SE, Sun WL. Tumor necrosis factor-alpha augments pulmonary arterial transendothelial albumin flux in vitro. Am J Physiol 1990; 258: L57-67.

35. Luscinskas, FW, Brock AF, Arnout MA, Gimbrone Jr MA. ELAM-1 dependent and leukocyte (CD11/CD18)dependent mechanism contribute to PMN leucocyte adhesion to cytokine-activated human vascular endothelium. J Immunol 1989; 142: 2257-2263.

36. Bevilacqua MP, Pober JS, Wheeler ME, Mendrick D, Cotran RS, Gimbrone MA. Interleukin-1 acts on cultured vascular endothelium to increase the adhesion of polymorphonuclear leukocytes, monocytes and related leukocyte cell lines. J Clin Invest 1985; 76: 2003 2011.

37. Dustin ML, Singer KH, Tuck DT, Springer TA. Adhesion of T-lymphoblasts to epidermal keratinocytes is regulated by IFN- $\gamma$ and is mediated by ICAM-1. J Exp Med 1988; 167: 1323-1340.

38. Wellicome SM, Thornhill MH, Pitzalis C, et al. A monoclonal antibody that detects a novel antigen on endothelial cells that is induced by TNF, IL-1 or lipopolysaccharide. J Immunol 1990; 144: 2558-2565.

39. Kips JC, Tavernier J, Pauwels RA. Tumor necrosis factor causes bronchial hyperresponsiveness in rats. Am Rev Respir Dis 1992; 145: 332-336.

40. Xing C, Jordana M, Kirpalani H, Driscoll KE, Schall T, Gauldie J. Cytokine expression by neutrophils and macrophages in vivo: endotoxin induces tumor necrosis factor- $\alpha$, macrophage inflammatory protein-2, interleukin- $1 \beta$, and interleukin- 6 but not RANTES or transforming growth factor- $1 \beta$ mRNA expression in acute lung inflammation. Am J Respir Cell Mol Biol 1994; 10: $148-153$. 